\title{
Selective in vitro targeting of GRP and NMB receptors in human tumours with the new bombesin tracer ${ }^{177}$ Lu-AMBA
}

\author{
Beatrice Waser ${ }^{1}$, Véronique Eltschinger ${ }^{1}$, Karen Linder ${ }^{2}$, Adrian Nunn², Jean Claude Reubi ${ }^{1}$ \\ ${ }^{1}$ Division of Cell Biology and Experimental Cancer Research, Institute of Pathology, University of Berne, P.O. Box 62, Murtenstrasse 31,3010 \\ Bern, Switzerland \\ ${ }^{2}$ Bracco Research USA Inc, Princeton, NJ, USA
}

Received: 20 April 2006 / Accepted: 17 July 2006 / Published online: 15 August 2006

(C) Springer-Verlag 2006

\begin{abstract}
Purpose: To investigate the in vitro binding properties of a novel radiolabelled bombesin analogue, ${ }^{177} \mathrm{Lu}-\mathrm{AMBA}$, in human neoplastic and non-neoplastic tissues selected for their expression of the bombesin receptor subtypes GRP-R, NMB-R and BRS-3.

Methods: In vitro receptor autoradiography was performed in cancers expressing the various bombesin receptor subtypes. The novel radioligand ${ }^{177} \mathrm{Lu}$-AMBA was used and compared with established bombesin radioligands such as ${ }^{125} \mathrm{I}_{-} \mathrm{Tyr}^{4}$-bombesin and ${ }^{125} \mathrm{I}-\left[\mathrm{D}-\mathrm{Tyr}^{6}, \beta-\mathrm{Ala}^{11}\right.$, $\left.\mathrm{Phe}^{13}, \mathrm{Nle}^{14}\right]$-bombesin(6-14). In vitro incidence of detection of each of the three bombesin receptor subtypes was evaluated in each tumour.

Results: ${ }^{177}$ Lu-AMBA identified all GRP-R-expressing tumours, such as prostatic, mammary and renal cell carcinomas as well as gastrointestinal stromal tumours. ${ }^{177} \mathrm{Lu}-\mathrm{AMBA}$ also identified all NMB-expressing tumours, but did not detect BRS-3-expressing tumours or BRS-3expressing pancreatic islets. GRP-R-expressing peritumoural vessels were heavily labelled with ${ }^{177} \mathrm{Lu}$-AMBA. In contrast to the strongly GRP-R-positive mouse pancreas, the human pancreas was not labelled with ${ }^{177} \mathrm{Lu}$-AMBA unless chronic pancreatitis was diagnosed. In general, the sensitivity was slightly better with ${ }^{177} \mathrm{Lu}$-AMBA than with the conventional bombesin radioligands.

Conclusion: The present in vitro study suggests that ${ }^{177} \mathrm{Lu}-$ AMBA may be a very useful in vivo targeting agent for GRP-R-expressing tumours, NMB-R-expressing tumours and GRP-R-expressing neoangiogenic vessels.
\end{abstract}

Keywords: Receptor binding - Radiopharmacy Tumour targeting - Molecular imaging Radiolabelled peptides

\footnotetext{
Jean Claude Reubi (

Division of Cell Biology and Experimental Cancer Research, Institute of Pathology,

University of Berne,

P.O. Box 62, Murtenstrasse 31,

3010 Bern, Switzerland

e-mail: reubi@pathology.unibe.ch

Tel.: +41-31-6323242, Fax: +41-31-6328999
}

\author{
Eur J Nucl Med Mol Imaging (2007) 34:95-100 \\ DOI 10.1007/s00259-006-0229-9
}

\section{Introduction}

Peptide hormones and their receptors not only are very important physiological regulators but also are becoming increasingly relevant in tumour management: many malignant human tumours overexpress various peptide hormone receptors, which can be used for in vivo tumour targeting [1]. For instance, the high expression of somatostatin receptors in gastroenteropancreatic neuroendocrine tumours allows highly effective somatostatin receptor targeted tumour imaging and therapy using radiolabelled somatostatin analogues [2-4].

Recently, other peptides and their receptors have attracted increasing interest, such as cholecystokinin, neurotensin and bombesin receptors [1]. Bombesin receptors are of particular interest, since widely occurring tumours such as prostate and breast cancers often express bombesin receptors [5, 6]. Moreover, it has also been reported that radiolabelled bombesin analogues can successfully image these tumours in vivo [7,8]. Finally, a large number of suitable radiopharmaceuticals have been synthesised and characterised for this purpose [9-11]. One of the most recent and most extensively characterised radiopharmaceuticals of this type is ${ }^{177} \mathrm{Lu}$-AMBA [12]. The unlabelled AMBA (DO3A-CH ${ }_{2} \mathrm{CO}-\mathrm{G}-4$-aminobenzoyl-Q-W-A-V-G-H-L-M$\mathrm{NH}_{2}$ ) binds with high affinity to gastrin-releasing peptide (GRP) and neuromedin B (NMB) receptors, while it has no affinity for BRS-3 receptors [12]. It has an excellent pharmacokinetic profile [12] and has been found to inhibit tumour growth in PC3 tumour-bearing mice [12]. This compound is presently in phase I clinical trials.

The aim of the present study was to investigate the in vitro binding characteristics of the novel radiolabelled bombesin analogue ${ }^{177} \mathrm{Lu}$-AMBA, using a selection of human tissues expressing the various bombesin receptors. The method used for this purpose was bombesin receptor 
autoradiography, as described previously [13]. The results, using ${ }^{177} \mathrm{Lu}$-AMBA as radioligand, were compared with the results obtained with established bombesin radioligands, ${ }^{125} \mathrm{I}-\mathrm{Tyr}^{4}$-bombesin and the universal radioligand ${ }^{125} \mathrm{I}-\left[\mathrm{D}-\mathrm{Tyr}^{6}, \beta-\mathrm{Ala}^{11}, \mathrm{Phe}^{13}, \mathrm{Nle}^{14}\right]$-bombesin(6-14), in the same tissues. The investigated tissues were human cancers expressing GRP-R (also named $\mathrm{BB}_{2}$ ), NMB-R (also named $\mathrm{BB}_{1}$ ) or BRS-3 (also named $\mathrm{bb}_{3}$ ), non-neoplastic tissues including normal pancreas and colon, and chronic pancreatitis. The results of this study should permit identification of the most suitable tumour targets for clinical trials with this radiopharmaceutical. The data may also facilitate the interpretation of whole-body ${ }^{177} \mathrm{Lu}$-AMBA scans with regard to the labelling of normal, non-neoplastic tissues.

\section{Materials and methods}

In vitro receptor autoradiography was performed in selected cancers and non-neoplastic tissues tested in previous studies for their bombesin receptor expression. They are listed in Table 1. Cryostat sections $(20 \mu M)$ of the tissue samples were prepared. Several radioligands were used in parallel in these experiments. The radioligand tested was ${ }^{177} \mathrm{Lu}-\mathrm{AMBA}$, radiolabelled by Bracco, Inc. [12] (Princeton, NJ) and shipped to Switzerland. All experiments with this radioligand were performed within 1 week after labelling. For comparison, receptor autoradiography was also performed with other bombesin radioligands, such as ${ }^{125} \mathrm{I}-\mathrm{Tyr}^{4}$-bombesin, known to preferentially label GRP receptors [14], and the newly developed radioligand ${ }^{125} \mathrm{I}-\left[\mathrm{D}-\mathrm{Tyr}{ }^{6}, \beta-\right.$ $\left.\mathrm{Ala}^{11}, \mathrm{Phe}^{13}, \mathrm{Nle}^{14}\right]$-bombesin(6-14), which has been reported to be an outstanding universal ligand that identifies all bombesin receptor subtypes $[13,15]$.

For autoradiography, tissue sections were mounted on precleaned microscope slides and stored at $-20^{\circ} \mathrm{C}$ for at least 3 days to improve adhesion of the tissue to the slide. The sections were first pre-incubated in $10 \mathrm{~m} M$ HEPES (pH 7.4) for $5 \mathrm{~min}$ at room temperature. They were then incubated in $10 \mathrm{~m} M$ HEPES, $130 \mathrm{~m} M \mathrm{NaCl}, 4.7 \mathrm{~m} M$ KCI, $5 \mathrm{~m} M$ $\mathrm{MgCl}_{2}, 1 \mathrm{~m} M$ ethylene glycol-bis ( $\beta$-aminoethylether)- $N$ - $N{ }^{\prime}$-tetraacetic acid, $0.1 \%$ BSA, $100 \mu \mathrm{g} / \mathrm{ml}$ bacitracin $(\mathrm{pH} \mathrm{7.4)}$ and one of the radioligands for $1 \mathrm{~h}$ at room temperature. ${ }^{177} \mathrm{Lu}-\mathrm{AMBA}(1.5 \mathrm{Ci} / \mu \mathrm{mol})$ was added at a concentration of $100 \mathrm{p} M$ in the presence or absence of $0.05 \mu M$ AMBA. ${ }^{125} \mathrm{I}_{-T y r}{ }^{4}$-bombesin $(2 \mathrm{Ci} / \mu \mathrm{mol}$; Anawa, Wangen, Switzerland) was added in a concentration of $100 \mathrm{p} M$ in the presence or absence of $0.1 \mu M$ bombesin. In both cases, additional sections were incubated in the presence of increasing amounts of GRP, NMB or somatostatin (Bachem, Bubendorf, Switzerland) to generate competitive inhibition curves. The expressed bombesin receptor subtype was further characterised in the tissues by incubation with $20 \mathrm{p} M^{125} \mathrm{I}-[\mathrm{D}-$ $\left.\mathrm{Tyr}^{6}, \beta-\mathrm{Ala}^{11}{ }^{\mathrm{Ph}}{ }^{13}, \mathrm{Nle}^{14}\right]$-bombesin $(6-14)(2 \mathrm{Ci} / \mu \mathrm{mol}$; Anawa) in the absence of any competitor peptide, as well as in the presence of $50 \mathrm{n} M$ of one of the three unlabelled competitors $\left[\mathrm{D}-\mathrm{Tyr}^{6}, \beta-\mathrm{Ala}^{11}\right.$, $\mathrm{Phe}^{13}, \mathrm{Nle}^{14}$ ]-bombesin(6-14), GRP or NMB. This protocol has been shown to discriminate adequately between the three receptor subtypes GRP-R, NMB-R and BRS-3 [13, 16]. After incubation, the sections were washed four times for $2 \mathrm{~min}$ each in $10 \mathrm{~m} M$ HEPES with $0.1 \%$

Table 1. Comparison of the incidence of in vitro detection of bombesin receptor subtypes in various human tissues using the novel radioligand ${ }^{177} \mathrm{Lu}-\mathrm{AMBA}$ and ${ }^{125} \mathrm{I}$-[D-Tyr ${ }^{6}, \beta-\mathrm{Ala}^{11}$,Phe ${ }^{13}$,Nle ${ }^{14}$ ]-bombesin(6-14) or ${ }^{125} \mathrm{I}^{-\mathrm{Tyr}^{4}}$-bombesin

\begin{tabular}{|c|c|c|c|c|c|c|c|c|}
\hline \multirow[t]{3}{*}{ Tissues } & \multirow[t]{3}{*}{ No. } & \multirow{3}{*}{$\begin{array}{l}\text { Expressed bombesin } \\
\text { receptor subtype }\end{array}$} & \multicolumn{6}{|c|}{ Incidence of detection of receptor subtypes } \\
\hline & & & \multicolumn{3}{|c|}{ Using 177 Lu-AMBA } & \multicolumn{3}{|c|}{ Using standard BN radioligands ${ }^{\mathrm{a}}$} \\
\hline & & & GRP-R & NMB-R & BRS-3 & GRP-R & NMB-R & BRS-3 \\
\hline \multicolumn{9}{|l|}{ Neoplasia } \\
\hline Mammary ca & 8 & GRP-R & $8 / 8$ & $0 / 8$ & $0 / 8$ & $8 / 8$ & $0 / 8$ & $0 / 8$ \\
\hline Prostate ca & 4 & GRP-R & $4 / 4$ & $0 / 4$ & $0 / 4$ & $4 / 4$ & $0 / 4$ & $0 / 4$ \\
\hline Renal cell ca & 6 & GRP-R & $5 / 6$ & $0 / 6$ & $0 / 6$ & $4 / 6$ & $0 / 6$ & $0 / 6$ \\
\hline GIST & 8 & GRP-R & $7 / 8$ & $0 / 8$ & $0 / 8$ & $7 / 8$ & $0 / 8$ & $0 / 8$ \\
\hline Ileal carcinoid & 8 & NMB-R & $0 / 8$ & $8 / 8$ & $0 / 8$ & $0 / 8$ & $8 / 8$ & $0 / 8$ \\
\hline GIST & 1 & NMB-R & $0 / 1$ & $1 / 1$ & $0 / 1$ & $0 / 1$ & $1 / 1$ & $0 / 1$ \\
\hline Bronchial carcinoid & 6 & BRS-3/GRP-R & $2(\mathrm{ld}) / 6$ & $0 / 6$ & $0 / 6$ & $2(\mathrm{ld}) / 6$ & $0 / 6$ & $6 / 6$ \\
\hline \multicolumn{9}{|l|}{ Colon ca } \\
\hline Tumour & 7 & GRP-R & $3(\mathrm{ld}) / 7$ & $0 / 7$ & $0 / 7$ & $3(\mathrm{ld}) / 7$ & $0 / 7$ & $0 / 7$ \\
\hline Smooth muscle & 7 & GRP-R & $7 / 7$ & $0 / 7$ & $0 / 7$ & $7 / 7$ & $0 / 7$ & $0 / 7$ \\
\hline Pancreas ca & 4 & - & $0 / 4$ & $0 / 4$ & $0 / 4$ & $0 / 4$ & $0 / 4$ & $0 / 4$ \\
\hline Peritumoural vessels around neoplasia ${ }^{b}$ & 6 & GRP-R & $6 / 6$ & $0 / 6$ & $0 / 6$ & $6 / 6$ & $0 / 6$ & $0 / 6$ \\
\hline \multicolumn{9}{|l|}{ Non-neoplastic tissue } \\
\hline Chronic pancreatitis (acini) & 5 & GRP-R & $5 / 5$ & $0 / 5$ & $0 / 5$ & $5 / 5$ & $0 / 5$ & $0 / 5$ \\
\hline Human pancreas (acini) & 7 & - & $1(\mathrm{ld}) / 7^{\mathrm{c}}$ & $0 / 7$ & $0 / 7$ & $0 / 7$ & $0 / 7$ & $0 / 7$ \\
\hline Mouse pancreas (acini) & 4 & GRP-R & $4 / 4$ & $0 / 4$ & $0 / 4$ & $4 / 4$ & $0 / 4$ & $0 / 4$ \\
\hline \multirow{2}{*}{\multicolumn{9}{|c|}{$\begin{array}{l}\text { The tested tumours represent a selection of tumours characterised for bombesin recept } \\
\text { not reflect the naturally occurring incidence. } \\
B N \text { bombesin, ld samples with a low density of receptors } \\
\text { a } 125 \mathrm{I}_{-} \mathrm{Tyr}^{4} \text {-bombesin and } 125 \mathrm{I}-\left[\mathrm{D}-\mathrm{Tyr}^{6}, \beta-\mathrm{Ala}^{11}, \mathrm{Phe}^{13}, \mathrm{Nle}^{14}\right] \text {-bombesin(6-14) }\end{array}$}} \\
\hline & & & & & & & & b Endometrial and pancreatic carcinomas \\
\hline
\end{tabular}


BSA ( $\mathrm{pH} 7.4)$ at $4^{\circ} \mathrm{C}$. Finally, the slides were rinsed twice for $5 \mathrm{~s}$ each at $4^{\circ} \mathrm{C}$ in HEPES without BSA. The slides were then dried under a stream of cold air. They were placed in apposition to Biomax MR films (Eastman Kodak, Rochester, NY) and exposed for 2 days $\left({ }^{177} \mathrm{Lu}\right)$ or for 7 days $\left({ }^{125} \mathrm{I}\right)$ in X-ray cassettes.

\section{Results}

Table 1 summarises the results. Prostatic, mammary and renal cell carcinomas, as well as the gastrointestinal stromal tumours (GIST), all identified as GRP-R-expressing tumours with established bombesin radioligands, were very well detected with in vitro receptor autoradiography using ${ }^{177} \mathrm{Lu}$-AMBA. Some of the tumours with low levels of GRP-R could still be identified with ${ }^{177}$ Lu-AMBA, while they were not detected with ${ }^{125} \mathrm{I}_{-} \mathrm{Tyr}^{4}$-bombesin or ${ }^{125} \mathrm{I}$-[D$\left.\mathrm{Tyr}^{6}, \beta-\mathrm{Ala}^{11}, \mathrm{Phe}^{13}, \mathrm{Nle}^{14}\right]$-bombesin(6-14) (Table 1), reflecting a slightly better sensitivity of the ${ }^{177}$ Lu-AMBA tracer, probably owing to its higher affinity and/or its different radioisotope.

All tumours that had been identified as NMB-Rexpressing tumours with established radioligands were also visualised with ${ }^{177} \mathrm{Lu}$-AMBA. Conversely, none of the BRS-3-expressing tumours were detected with ${ }^{177} \mathrm{Lu}-$ AMBA. By way of example, Fig. 1a shows a GRP-R-
Fig. 1. a Detection of GRP-R in successive sections of a prostate cancer by the universal bombesin radioligand ${ }^{125} \mathrm{I}-\left[\mathrm{D}-\mathrm{Tyr}^{6}\right.$, $\beta-\mathrm{Ala}^{11}, \mathrm{Phe}^{13}, \mathrm{Nle}^{14}$ ]-bombesin (6-14) (A-D) and by ${ }^{177} \mathrm{Lu}-$ AMBA (E-H). A,E Autoradiograms showing total binding of ${ }^{125} \mathrm{I}-\left[\mathrm{D}-\mathrm{Tyr}^{6}, \beta-\mathrm{Ala}^{11}, \mathrm{Phe}^{13}\right.$, $\mathrm{Nle}^{14}$ ]-bombesin(6-14) (A) or ${ }^{177}$ Lu-AMBA (E) in tumour tissue (Tu). Bar=1 mm. B,F Autoradiograms showing nonspecific binding in the presence of $50 \mathrm{n} M$ of $\left[\mathrm{D}-\mathrm{Tyr}^{6}, \beta-\mathrm{Ala}^{11}\right.$, $\mathrm{Phe}^{13}, \mathrm{Nle}^{14}$ ]-bombesin $(6-14)$ (B) and AMBA (F). C,G Autoradiograms showing binding in the presence of $50 \mathrm{n} M$ GRP. D,H Autoradiograms showing binding in the presence of $50 \mathrm{n} M$ NMB. Complete displacement of each ligand in the tumour is seen with GRP but not with NMB. b Detection of NMB-R in successive sections of an ileal carcinoid by ${ }^{125} \mathrm{I}-\left[\mathrm{D}-\mathrm{Tyr}^{6}, \beta-\mathrm{Ala}^{11}, \mathrm{Phe}^{13}\right.$, $\mathrm{Nle}^{14}$ ]-bombesin(6-14) (A-D) and by ${ }^{177}$ Lu-AMBA (E-H). Same legend as in a. Complete displacement of each ligand in the tumour is seen with NMB but not with GRP. c Detection of BRS-3 in successive sections of a bronchial carcinoid by ${ }^{125}$ I- $\left[\mathrm{D}-\mathrm{Tyr}^{6}, \beta-\mathrm{Ala}^{11}, \mathrm{Phe}^{13}\right.$, $\mathrm{Nle}^{14}$ ]-bombesin(6-14) (A-D) but not by ${ }^{177} \mathrm{Lu}-\mathrm{AMBA}(\mathbf{E}-\mathbf{H})$. Same legend as in a. Complete displacement of ${ }^{125} \mathrm{I}-\left[\mathrm{D}-\mathrm{Tyr}{ }^{6}\right.$, $\beta$-Ala $\left.{ }^{11}, \mathrm{Phe}^{13}, \mathrm{Nle}^{14}\right]$-bombesin (6-14) is obtained with the universal ligand (B) but not with GRP (C) or NMB (D). ${ }^{177}$ Lu-AMBA does not label the tumour at all $(\mathbf{E})$

\section{a) GRP - $R$ expressing prostate cancer}
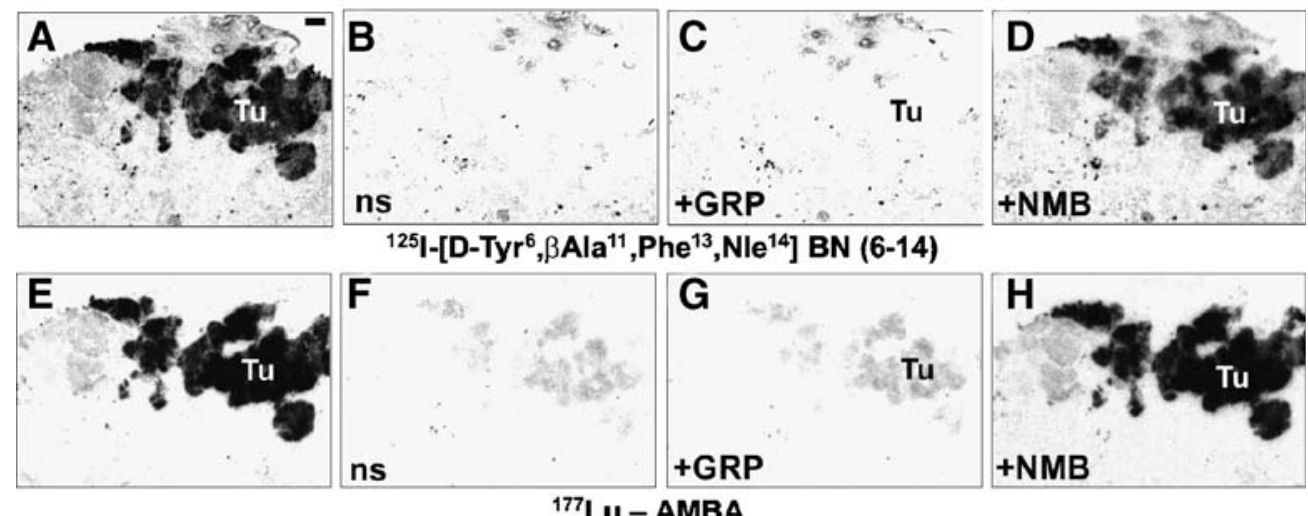

b) NMB - R expressing ileal carcinoid
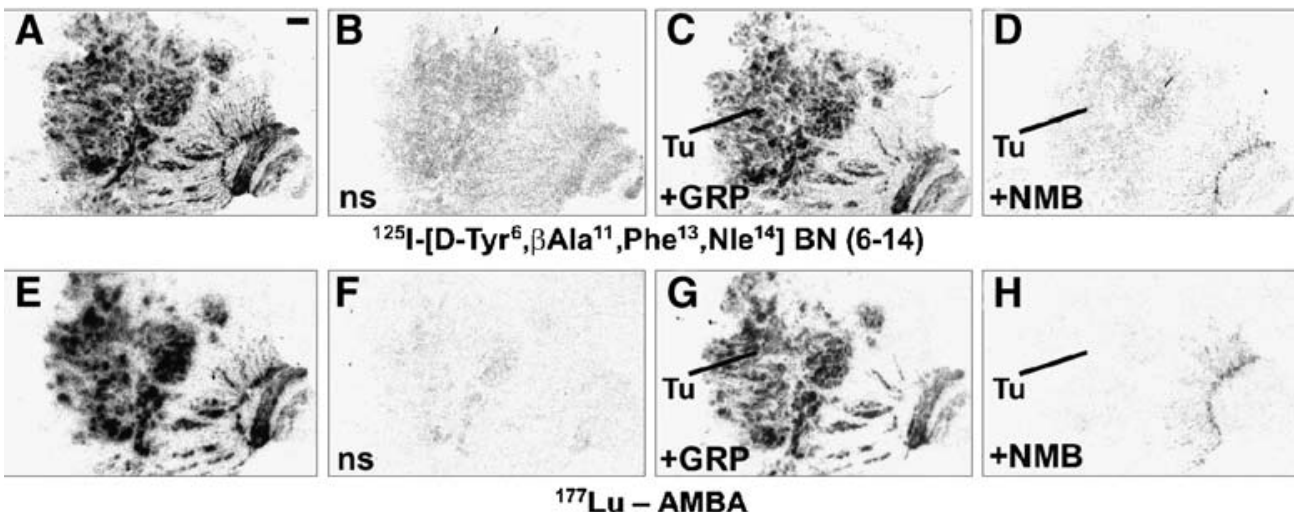

${ }^{177}$ Lu - AMBA

c) $b b_{3}-R$ expressing bronchial carcinoid
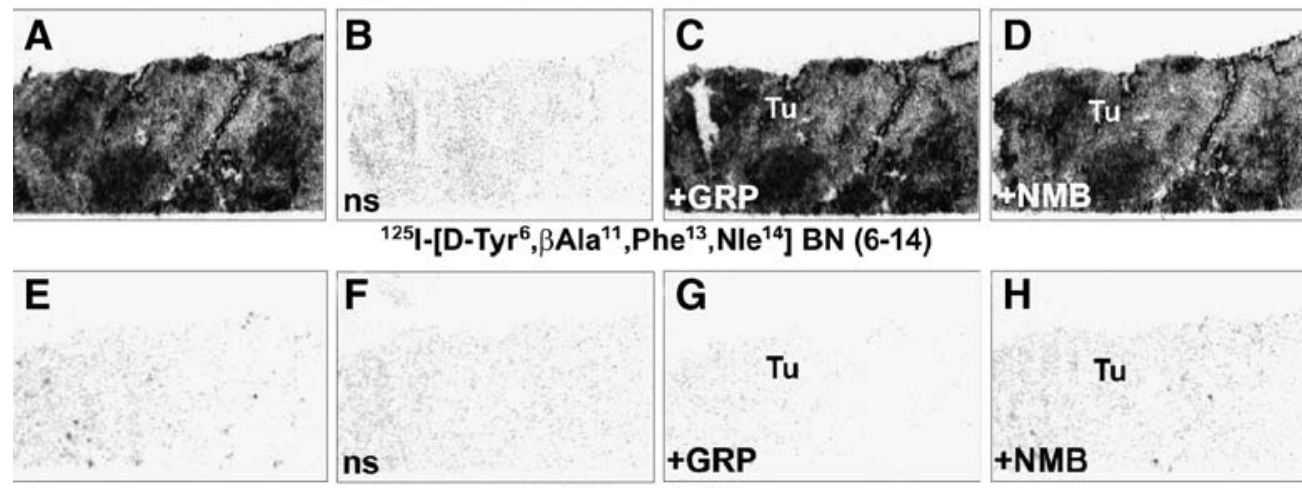

H

Tu
+ NMB

${ }^{177}$ Lu - AMBA 
Fig. 2. ${ }^{177}$ Lu-AMBA labels very strongly the acini of the mouse pancreas $(\mathbf{F}-\mathbf{K})$ but not those of the human pancreas $(\mathbf{A}-\mathbf{E})$. A,F Haematoxylin and eosin-stained sections. Bars $=1 \mathrm{~mm}$. B,G Autoradiograms showing total binding of ${ }^{177} \mathrm{Lu}-\mathrm{AMBA}$. Labelling is absent in $\mathbf{B}$, strong in $\mathbf{G}$. $\mathbf{C , H}$ Autoradiograms showing non-specific binding (in the presence of $50 \mathrm{n} M$ AMBA). D,I Autoradiograms showing binding in the presence of $50 \mathrm{n} M$ GRP. E,K Autoradiograms showing binding in the presence of $50 \mathrm{n} M \mathrm{NMB}$
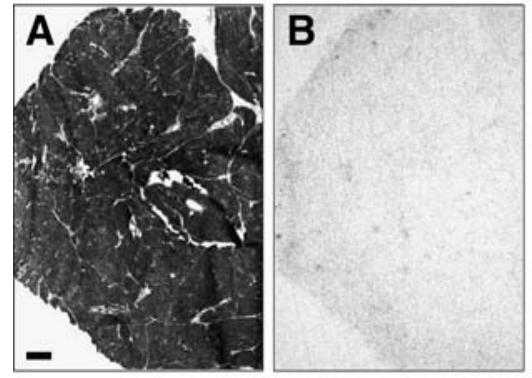

\section{human}

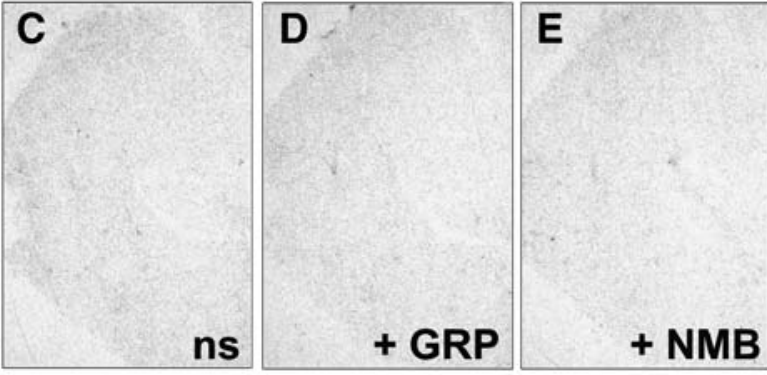

mouse
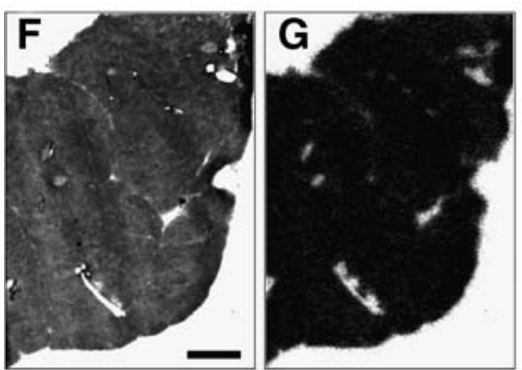
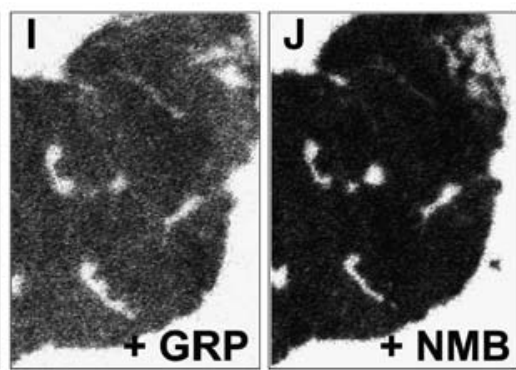
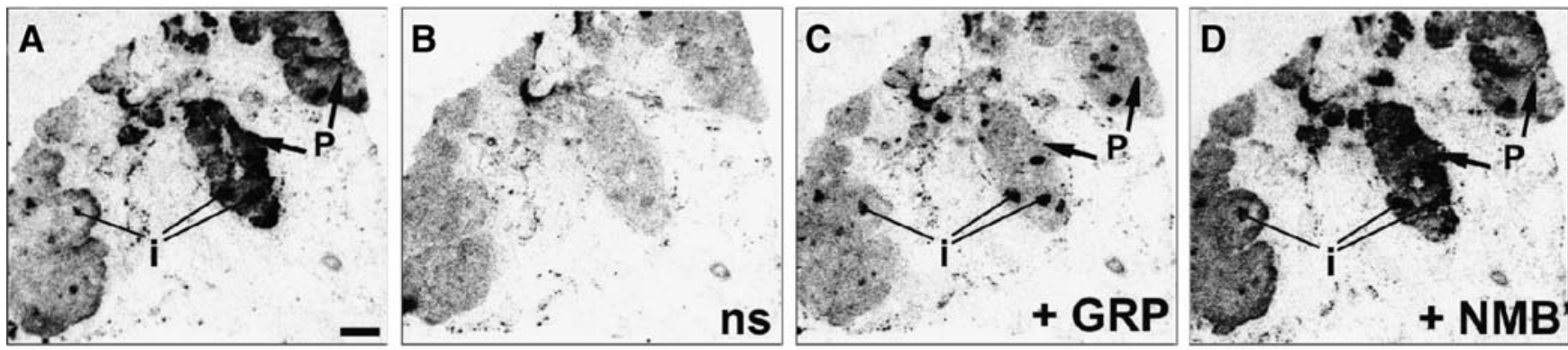

${ }^{125}$ I-[D-Tyr $\left.{ }^{6}, \beta A l a^{11}, \mathrm{Phe}^{13}, \mathrm{Nle}^{14}\right] \mathrm{BN}(6-14)$
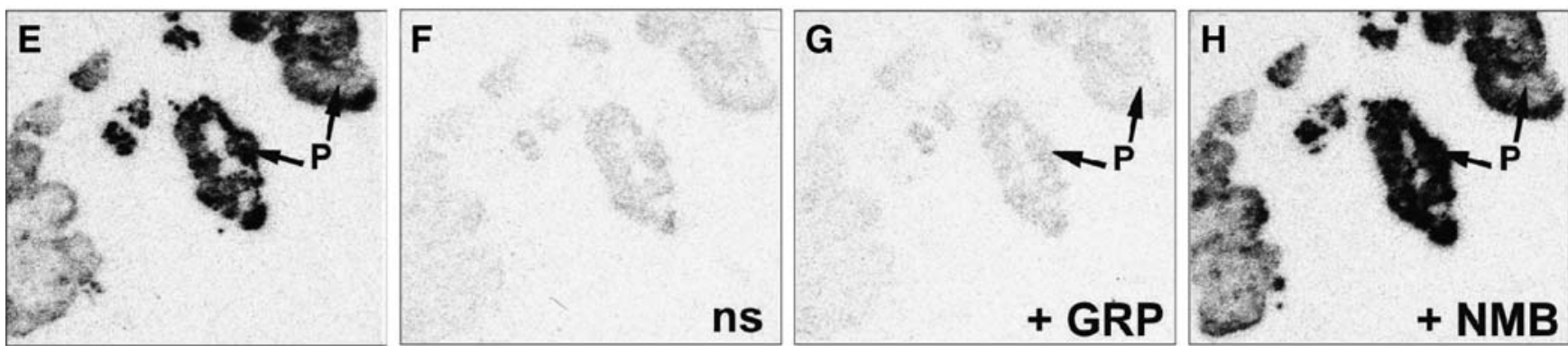

${ }^{177}$ Lu - AMBA

Fig. 3. Detection of GRP-R-expressing pancreatic acini $(P)$ in a chronic pancreatitis by ${ }^{125} \mathrm{I}_{-}\left[\mathrm{D}-\mathrm{Tyr}^{6}, \beta-\mathrm{Ala}^{11}, \mathrm{Phe}^{13}, \mathrm{Nle}^{14}\right]$-bombesin (6-14) (A-D) and by ${ }^{177}$ Lu-AMBA (E-H). A,E Autoradiograms showing total binding of ${ }^{125} \mathrm{I}-\left[\mathrm{D}-\mathrm{Tyr}^{6}, \beta-\mathrm{Ala}^{11}, \mathrm{Phe}^{13}, \mathrm{Nle}^{14}\right]$-bombesin $(6-14)(\mathbf{A})$ or ${ }^{177} \mathrm{Lu}-\mathrm{AMBA}(\mathbf{E})$ in pancreatic acini $(P)$ or in islets $(i)$. $B a r=1 \mathrm{~mm}$. B,F Autoradiograms showing non-specific binding in the presence of $\left[\mathrm{D}-\mathrm{Tyr}^{6}, \beta-\mathrm{Ala}^{11}, \mathrm{Phe}^{13}, \mathrm{Nle}^{14}\right]$-bombesin(6-14) (B) and
AMBA (F). C,G Autoradiograms showing binding in the presence of $50 \mathrm{n} M$ GRP. D,H Autoradiograms showing binding in the presence of $50 \mathrm{n} M$ NMB. Displacement of each ligand in the pancreatic acini is seen with GRP but not with NMB. Note that the universal ligand, ${ }^{125} \mathrm{I}-\left[\mathrm{D}-\mathrm{Tyr}^{6}, \beta-\mathrm{Ala}^{11}, \mathrm{Phe}^{13}, \mathrm{Nle}^{14}\right]$-bombesin $(6-14)$, but not ${ }^{177} \mathrm{Lu}$ AMBA, also identifies the BRS-3-expressing islets $(i)$. In the islets, complete displacement is seen with the universal ligand only $(\mathbf{B})$ 
expressing prostate cancer labelled similarly with the universal ligand and with ${ }^{177}$ Lu-AMBA, Fig. $1 \mathrm{~b}$ shows an NMB-R-expressing ileal carcinoid identified with both tracers and Fig. 1c shows a BRS-3-positive bronchial carcinoid strongly labelled with the universal radioligand but not with ${ }^{177} \mathrm{Lu}$-AMBA. As the tested cases were all preselected and chosen as receptor positive in the majority of cases or as negative controls in a few selected cases, one should not draw any conclusions about the natural incidence of receptor expression in the various types of tumour listed in Table 1.

Figure 2 shows that the normal human pancreas, known to be devoid of GRP-R, is not labelled with ${ }^{177} \mathrm{Lu}$-AMBA, whereas the GRP-R-expressing mouse pancreas is strongly labelled with ${ }^{177} \mathrm{Lu}-\mathrm{AMBA}$ under identical experimental conditions. Moreover, the islets of the human pancreas, known to express BRS-3, were labelled with the universal tracer ${ }^{125}{ }^{2}-\left[\mathrm{D}-\mathrm{Tyr}^{6}, \beta-\mathrm{Ala}^{11}, \mathrm{Phe}^{13}, \mathrm{Nle}^{14}\right]$-bombesin $(6-14)$ but not with ${ }^{177}$ Lu-AMBA (Fig. 3). Finally, GRP-R were detected in human pancreatic tissues that are pathologically altered (chronic pancreatitis), indicating that GRP-R, when present in this human tissue, can be identified under the experimental conditions chosen in this study. In fact, ${ }^{177} \mathrm{Lu}-$ AMBA appears to identify these GRP-R in chronic pancreatitis with greater sensitivity than does ${ }^{125} \mathrm{I}-\mathrm{Tyr}^{4}$-bombesin, as illustrated in Fig. 3.

While none of the pancreatic cancers had measurable amounts of GRP-R with either tracer, a few colon carcinomas showed a low density of heterogeneously distributed GRP-R measured either with ${ }^{177} \mathrm{Lu}-\mathrm{AMBA}$ or with standard tracers (Table 1). It should further be noted that the smooth muscles of the colon express GRP-R in vitro, in quantities reaching the density level of many GRPR-expressing tumours; these muscular receptors were detected either with ${ }^{177} \mathrm{Lu}$-AMBA or with the established bombesin ligands.

Figure 4 shows two complete displacement curves for ${ }^{177} \mathrm{Lu}$-AMBA in the presence of various bombesin-like compounds in a GRP-R and an NMB-R-expressing tumour, illustrating the expected rank order of potency of analogues for the respective receptor.

\section{Discussion}

We showed in a previous report that ${ }^{175} \mathrm{Lu}$-AMBA has a very high affinity for human GRP and NMB receptors $\left(\mathrm{IC}_{50}\right.$ : 0.8 and $0.9 \mathrm{n} M$, respectively) expressed in human tissues while it has only low affinity for BRS-3 receptors $\left(\mathrm{IC}_{50}:>1,000 \mathrm{n} M\right)$ [12]. These experiments were performed with ${ }^{125} \mathrm{I}-\left[\mathrm{D}-\mathrm{Tyr}^{6}, \beta-\mathrm{Ala}^{11}, \mathrm{Phe}^{13}, \mathrm{Nle}^{14}\right]$-bombesin $(6-14)$ as radiotracer and cold ${ }^{175} \mathrm{Lu}$-AMBA as displacer. In the present study, we used the ${ }^{177} \mathrm{Lu}$-labelled AMBA as radiotracer, which corresponds exactly to the tracer that may be used in future for nuclear medicine purposes in vivo in humans. We can herewith markedly extend the preliminary data reported previously [12]: All GRP-Rexpressing human cancers were very strongly labelled with ${ }^{17} \mathrm{Lu}$-AMBA. The same was true for all NMB-R-positive
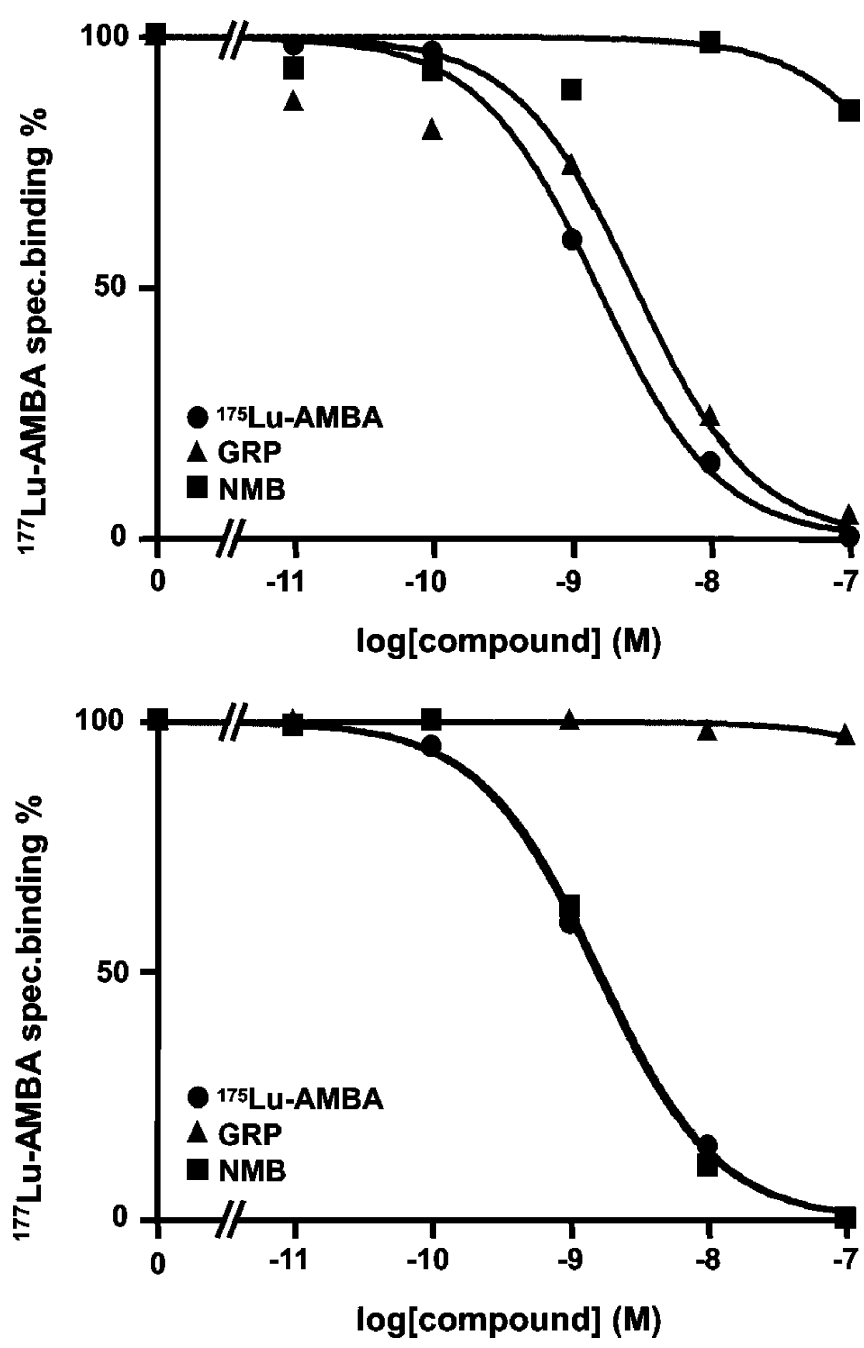

Fig. 4. Competition experiments with ${ }^{177} \mathrm{Lu}-\mathrm{AMBA}$ in a GRP-Rexpressing prostatic cancer (upper graph) and an NMB-R-expressing ileal carcinoid (lower graph). Displacement by AMBA (•), GRP $(\boldsymbol{\Delta})$ and NMB ( $\boldsymbol{\square})$. Rank order of potencies of compounds corresponds to the expressed bombesin receptor subtype

tumours. Conversely, tumours with BRS-3 receptors were not visualised. The sensitivity of ${ }^{177} \mathrm{Lu}$-AMBA appears

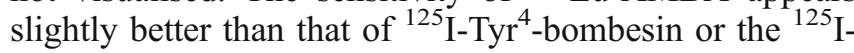
labelled universal bombesin analogue, although a direct comparison cannot be made owing to the different radioisotopes present in the two radiopharmaceuticals. It is to be noted that a few tumours expressing a low density of GRP-R could be readily identified with ${ }^{177} \mathrm{Lu}-\mathrm{AMBA}$ while they remained negative with ${ }^{125} \mathrm{I}-\mathrm{Tyr}^{4}$-bombesin. Of further interest is the fact that GRP-R-positive peritumoural vessels were readily identified with ${ }^{177} \mathrm{Lu}-\mathrm{AMBA}$ as well as with standard tracers. The present study therefore strongly suggests that ${ }^{177} \mathrm{Lu}$-AMBA will be a targeting tool for GRP-R-expressing tumour cells and for neoangiogenic vessels simultaneously.

The binding characteristics of ${ }^{177} \mathrm{Lu}-\mathrm{AMBA}$ could also be confirmed in non-neoplastic tissues. While the mouse pancreas, as control, was shown to express a very high density of GRP-R, the normal human pancreatic acini were 
devoid of measurable amounts of GRP-R [17]. However, in conditions of chronic pancreatitis, GRP-R could be identified in acini, as reported previously [17], again with a better sensitivity when using ${ }^{177}$ Lu-AMBA than when using ${ }^{125} \mathrm{I}-T y r^{4}$-bombesin. Conversely, as expected, the BRS-3-expressing islets were not detected with ${ }^{177} \mathrm{Lu}-$ AMBA, while these same islets were strongly labelled with the universal ligand [17]. It should be stressed that the normal pancreas is a very rapidly degradable tissue; it is hardly possible to exclude degradation of proteins, including receptor proteins, in particular in the human pancreas, which may be resected under suboptimal conditions. Nevertheless, that the human pancreas data are truly negative data is indicated not only by the positive control of the mouse pancreas tested under similar experimental conditions but also by the strong labelling of BRS-3 receptors in the islets of the human pancreas, which represents a positive control for the quality of the investigated human pancreas. While a minority of colon carcinomas had GRP-R, usually in a very low density and with a heterogeneous distribution, the normal colonic smooth muscles expressed, as reported previously [18], a high density of GRP-R, all labelled with ${ }^{177} \mathrm{Lu}-\mathrm{AMBA}$. While the GRP-R density in the smooth muscles was lower than that in prostate cancers and lower than or comparable to that in breast cancers and GIST, it was higher than that in renal cell carcinomas.

This study suggests that ${ }^{177} \mathrm{Lu}-\mathrm{AMBA}$ is an excellent radioligand to target GRP-R and NMB-R-expressing human tumours, such as prostate, mammary and renal cell carcinomas (GRP-R), gastrointestinal stromal tumours (GRP-R) and ileal carcinoids (NMB-R), but also GRP-Rpositive peritumoural vessels. Further, this in vitro study seems to predict the absence of significant receptormediated in vivo uptake in the normal human pancreas (in contrast to very high uptake in the mouse pancreas), while in vivo uptake of ${ }^{177}$ Lu-AMBA may be foreseen in chronic pancreatitis and at the level of the colonic smooth muscles, both tissues expressing GRP-R. Based on these promising data, the development of ${ }^{177} \mathrm{Lu}$-AMBA for clinical use as a targeting agent may open exciting new opportunities in nuclear medicine.

Acknowledgements. We thank Dr. Jiaqing Chen for ${ }^{177}$ Lu-AMBA tracer preparation.

\section{References}

1. Reubi JC. Peptide receptors as molecular targets for cancer diagnosis and therapy. Endocr Rev 2003;24:389-427.

2. Krenning EP, Bakker WH, Breeman WAP, Koper JW, Kooij PPM, Ausema L, et al. Localisation of endocrine-related tumours with radioiodinated analogue of somatostatin. Lancet 1989;I:242-4.
3. Otte A, Mueller-Brand J, Dellas S, Nitzsche EU, Herrmann R, Maecke HR. Yttrium-90-labelled somatostatin-analogue for cancer treatment. Lancet 1998;351:417-8.

4. Kwekkeboom DJ, Bakker WH, Kam BL, Teunissen JJM, Kooij PP, Herder WW, et al. Treatment of patients with gastro-enteropancreatic (GEP) tumours with the novel radiolabelled somatostatin analogue $\left[{ }^{177} \mathrm{Lu}-\mathrm{DOTA}{ }^{0}, \mathrm{Tyr}^{3}\right]$ octreotate. Eur J Nucl Med Mol Imaging2003;30:417-22.

5. Markwalder R, Reubi JC. Gastrin-releasing peptide receptors in the human prostate: relation to neoplastic transformation. Cancer Res 1999;59:1152-9.

6. Gugger M, Reubi JC. GRP receptors in non-neoplastic and neoplastic human breast. Am J Pathol 1999;155:2067-76.

7. Van de Wiele C, Dumont F, Vanden Broecke R, Oosterlinck W, Cocquyt V, Serreyn R, et al. Technetium-99m RP527, a GRP analogue for visualisation of GRP receptor-expressing malignancies: a feasibility study. Eur J Nucl Med 2000;27:1694-9.

8. Scopinaro F, De Vincentis G, Varvarigou AD, Laurenti C, Iori F, Remediani S, et al. ${ }^{99 \mathrm{~m}} \mathrm{Tc}$-bombesin detects prostate cancer and invasion of pelvic lymph nodes. Eur J Nucl Med Mol Imaging 2003;30:1378-82.

9. Zhang H, Chen J, Waldherr C, Hinni K, Waser B, Reubi JC, et al. Synthesis and evaluation of bombesin derivatives on the basis of pan-bombesin peptides labeled with indium-111, lutetium-177, and yttrium-90 for targeting bombesin receptorexpressing tumors. Cancer Res 2004;64:6707-15.

10. Nock BA, Nikolopoulou A, Galanis A, Cordopatis P, Waser B, Reubi JC, et al. Potent bombesin-like peptides for GRPreceptor targeting of tumors with ${ }^{99 \mathrm{~m}} \mathrm{Tc}$ : a preclinical study. J Med Chem 2005;48:100-10.

11. Maina T, Nock BA, Zhang H, Nikolopoulou A, Waser B, Reubi $\mathrm{JC}$, et al. Species differences of bombesin analog interactions with GRP-R define the choice of animal models in the development of GRP-R-targeting drugs. J Nucl Med 2005;46:823-30.

12. Lantry LE, Cappelletti E, Maddalena ME, Fox JS, Feng W, Chen J, et al. ${ }^{177}$ Lu-AMBA: synthesis and characterization of a selective ${ }^{177}$ Lu-labeled GRP receptor agonist for systemic radiotherapy of prostate cancer. J Nucl Med 2006;47:1144-52.

13. Reubi JC, Wenger S, Schmuckli-Maurer J, Schaer JC, Gugger $\mathrm{M}$. Bombesin receptor subtypes in human cancers: detection with the universal radioligand ${ }^{125} \mathrm{I}-\left[\mathrm{D}-\mathrm{TYR}^{6}\right), \beta-\mathrm{ALA}^{11}, \mathrm{PHE}^{13}$, $\left.\mathrm{NLE}^{14}\right]$ bombesin(6-14). Clin Cancer Res 2002;8:1139-46.

14. Vigna SR, Mantyh CR, Giraud AS, Soll AH, Walsh JH, Mantyh PW. Localization of specific binding sites for bombesin in the canine gastrointestinal tract. Gastroenterology 1987;93:1287-95.

15. Pradhan TK, Katsuno T, Taylor JE, Kim SH, Ryan RR, Mantey $\mathrm{SA}$, et al. Identification of a unique ligand which has high affinity for all four bombesin receptor subtypes. Eur J Pharmacol 1998;343:275-87.

16. Reubi JC, Waser B. Concomitant expression of several peptide receptors in neuroendocrine tumors as molecular basis for in vivo multireceptor tumor targeting. Eur J Nucl Med Mol Imaging 2003;30:781-93.

17. Fleischmann A, Läderach U, Friess H, Buechler M, Reubi JC. Bombesin receptors in distinct tissue compartments of human pancreatic diseases. Lab Invest 2000;80:1807-17.

18. Rettenbacher M, Reubi JC. Localization and characterization of neuropeptide receptors in human colon. Naunyn-Schmiedebergs Arch Pharmacol 2001;364:291-304. 